Pamiętnik Literacki 2015, 2, s. 177-184
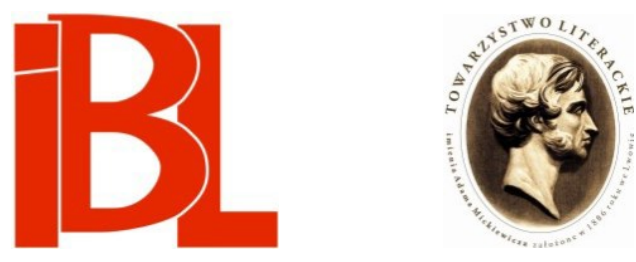

\title{
Sienkiewicz, generał Custer i Indianie
}

\author{
Jerzy R. Krzyżanowski
}




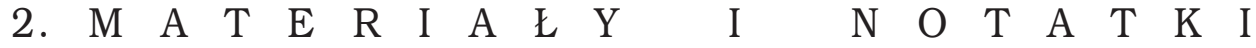

Pamiętnik Literacki CVI, 2015, z. 2, PL ISSN 0031-0514

JERZY R. KRZYŻANOWSKI Columbus State University, Ohio, USA

\section{SIENKIEWICZ, GENERAE CUSTER I INDIANIE}

Jedną $z$ recept na napisanie udanego reportażu jest umiejętność znalezienia się we właściwym miejscu we właściwym czasie. Jeśli przyjmiemy tę definicję, możemy zastosować ją w pełni do początków dziennikarskiej kariery Henryka Sienkiewicza, zainicjowanej udanym reportażem z pożaru Pułtuska w lipcu 1875. W niecały rok później, w lutym 1876, Sienkiewicz wyruszył na światowej skali reporterski szlak, jako jeden z nielicznych wtedy dziennikarzy jadąc do Ameryki, skąd nadsyłać zaczą do redakcji „Gazety Polskiej” kolejne „listy z podróży do Ameryki”, po latach włączone do wydania jego Dziet (t. 41-42. Warszawa 1950).

I mimo że tematy tych reportaży pozornie odnoszą się do „właściwego czasu”, tzn. do lat 1876-1878, obejmujących okres pobytu Sienkiewicza w Stanach Zjednoczonych, ich zasieg jest o wiele obszerniejszy niż „chwila obecna” - jak pisarz nazwać miał swoje późniejsze felietony - mówią one bowiem zarówno o geografii, jak historii tego olbrzymiego kraju, który Sienkiewicz stopniowo poznawał podróżując od Atlantyku po Pacyfik i zwiedzając szereg wschodnich, a następnie zachodnich stanów. Młody, zaledwie 30-letni dziennikarz, bez większego doświadczenia reporterskiego, okazał się nie tylko bystrym obserwatorem, ale także zdolnym socjo- i politologiem, analitykiem spraw napotykanych w drodze - zdawałoby się, egzotycznych dla warszawskiego dziennikarza-literata, choć mających znaczenie szersze niż wyłącznie lokalne. Jedną $z$ nich była prowadzona bezlitośnie wojna z Indianami, której cel stanowiło niemal zupełne wyniszczenie pierwotnych mieszkańców kraju. Sienkiewicz śledził ją zarówno $z$ okna wagonu, mijając tereny bieżąco toczonych walk, jak i wychwytując $z$ prasy najnowsze wiadomości, do Polski docierające tylko połowicznie, najczęściej z dużym opóźnieniem, gdy tymczasem w Stanach były to rzeczy zasadnicze, kształtujące na całe dziesięciolecia politykę wewnętrzną kraju, z jej zdobyczami i błędami, mającymi znaczenie jeszcze dzisiaj, po prawie 150 latach. Dla polskiego pisarza o wyrobionej wrażliwości na problemy etniczne i kwestię supremacji jednego narodu nad drugim sprawy te były nie tylko żywe, ale wręcz fascynujące.

Podczas gdy zagadnienie zniesienia niewolnictwa i w ogóle - miejsca Murzynów w nowym, demokratycznym społeczeństwie, o co wcześniej toczono okrutną wojnę domowa, nie wysuwało się na czoło w publicystyce lat siedemdziesiątych XIX wie$\mathrm{ku}$, problemy Indian walczacych o utrzymanie swego etosu zyskiwały stopniowo pierwsze miejsce, w miarę jak zaostrzały się walki na terytoriach centralnych stanów, będących terenem zbrojnego oporu przeciw polityce władz Waszyngtonu. Istnieje na ten temat olbrzymia literatura historyczna i beletrystyczna, odsyłając 
więc do niej czytelnika, zatrzymajmy się na dorobku Sienkiewicza w owej dziedzinie, a zwłaszcza na ostatnim rozdziale tej okrutnej historii, jakim był bezlitosny pogrom armii amerykańskiej dokonany przez zmasowane siły Indian pod dowództwem ich wybitnego wodza o nazwisku Sitting Bull (Siedzacy Byk). Sienkiewicz był niemal naocznym świadkiem tych wydarzeń, znalazłszy się przypadkiem „we właściwym miejscu we właściwym czasie”. Dodajmy od razu, że nie dosłownie, gdyż miejsce, w którym się zatrzymał w drodze do Kalifornii i w którym napotkał Indian, a mianowicie Ketchum w stanie Idaho, oddalone jest od sceny porażki wojsk amerykańskich w bitwie $z$ Indianami w Południowej Dakocie o jakieś - bagatela - 800 kilometrów w linii powietrznej; niemniej jednak, biorąc pod uwagę amerykańskie odległości, powiedzieć można, że Sienkiewicz był od terenu przedstawianych wypadków względnie blisko, na pewno zaś bliżej niż którykolwiek z piszących na ten temat Polaków, a nawet Amerykanów.

Wyruszywszy około 5 marca 1876 z Nowego Jorku otwartą właśnie w owym czasie „Koleją Dwóch Oceanów”, Sienkiewicz po krótkich postojach w Detroit i Chicago zagłębił się w niezmierzone obszary Środkowego Zachodu, gdzie wreszcie zetknąc się miał z Indianami. W Ketchum, „małej stacji leżącej na skraju Jowy [!], niedaleko od Omaha” - jak relacjonuje - „ujrzał po raz pierwszy dzikich Indian” (L 139) ${ }^{1}$. Zaciekawiony, spytał współpasażerów, czemu się przypatrują:

Odpowiedziano mi, że jest to poselstwo Siouxów jadące na wschód do Granta lub, co prawdopodobniej, do gubernatora Jowy, lub, na koniec, jakiegoś generała, głównodowodzącego wojskami koło Black Hills. Inni twierdzili, że są to Indianie wezwani na wystawę do Filadelfii. [L 139-140]

Spotkanie to, o którym będzie dalej mowa, przypadło przypuszczalnie na dzień 11 lub 12 marca, datę o tyle ważną, że była ona początkiem kampanii generała Custera przeciw Indianom. Zanim jednak do dziejów tej kampanii przejdziemy, przypomnijmy najpierw, co Sienkiewicz pisał o paśmie gór Black Hills, w których kierunku zmierzał wśród tłumów pasażerów jadących tam na wieść o odkryciu złota:

tymczasem ten raj wymarzony niejednemu grobem się stanie, tak bowiem cały kraj wokoło, jak i Czarne Góry są własnością Siouxów, najliczniejszego z plemion indyjskich, mogącego wystawić dziesięć tysięcy wojowników. Własność Czarnych Gór została im przyznana i zagwarantowana dawniej jeszcze przez rząd Stanów Zjednoczonych; dlatego topór wojenny długo leżał pogrzebany między czerwonymi a białymi. Ale teraz rzeczy się zmieniły. Tłumy białych awanturników, nie pytając o układy rządowe, rzuciły się w góry. Rząd wprawdzie w takich razach nie daje im opieki ani posyła wojsk na ich obronę, ale awanturnicy, zbrojni i przywykli do boju z Indianami, mniej jeszcze dbają o pomoc niż o układy i zabierają, co im się podoba. Taki stan rzeczy, który zresztą w całych Stanach jest ogólny, przyprowadził Indian do rozpaczy.

Na próżno wysyłają poselstwa, które pergaminami, pieczęciami i podpisami dowodzą swej własności. Rząd nie ma siły utrzymać awanturników; co więcej, gdy kraj jest już zajęty, gdy powznoszą się farmy i miasta, rządowi nie pozostaje nic innego, jak tylko usankcjonować zabór i doliczyć do Stanów jedno więcej terytorium. Tak dzieje się w Dakota, w Nebrasce, w Kansas, w Indian Territory, słowem: wszędzie. Rząd wyznacza dzikim ziemię, a biali ją zabierają i wytępiwszy Indian zakładają nowe stany.

$1 \quad$ Skrótem L odsyłam do: H. Si e nki ew i c z, Listy z podróży do Ameryki. Cz. 1. W: Dzieła. T. 41. Warszawa 1950. Ponadto stosuję skrót: $\mathrm{N}=\mathrm{H}$. S i e n k i e w i c z, Nowele amerykańskie. W: jw., t. 3 (1948). Liczby po skrótach wskazują stronice. 
Ale wobec tego, cóż pozostaje czerwonoskórym? Oto wojna i wojna, bez nadziei zwycięstwa, tylko o śmierć. Dziś czerwoni wojownicy wiedza już, że nie wytrzymają boju z „Długimi Nożami”, jak nazywają białych, idzie więc im o to, aby nie zginąć bez zemsty i żeby na tamtym świecie złożyć u nóg „Wielkiego Ducha” jak najwięcej krwawych skalpów zdartych z głów najeźdźców. Krótko mówiąc, rasa ta dzielna, choć dzika, ginie nieubłaganie na całej przestrzeni Stanów. $Z$ cywilizacją, która zresztą pod najgorszą postacią im się przedstawia, pogodzić się nie umieją i nie mogą, więc cywilizacja ta ściera ich z powierzchni ziemi równie nieubłaganie jak brutalnie.

Teraz przyszła kolej na Siouxów. Wojownicy ich pomalowali się ochrą i stanęli w gotowości do boju, który obecnie już się rozpoczął! Gazety są przepełnione opisami dramatycznych zajść w Czarnych Górach, które to opisy, częstokroć umyślnie przesadzone, podsycają tylko nienawiść białych i zamiast odstraszać, zachęcają tylko wszystkie niespokojne duchy do szukania krwawych awantur i do zemsty nad czerwonoskórymi. Niektóre z tych wieści brzmia jak prawdziwe romanse. [L 134-135]

Warto w ustępie tym zwrócić uwagę na wyraźną sympatię, z jaką Sienkiewicz pisze o Indianach, ponadto zaś podkreślić słowo „zabór”, mające dla polskiego czytelnika XIX wieku jednoznaczny wydźwięk polityczny, zwłaszcza po stosunkowo niedawnym powstaniu styczniowym.

Oczywiście, istnieje zapewne bardzo mało wojowników, którzy mają dość siły woli, aby w danym razie odpowiedzieć godnie powyższemu ideałowi [tj. wizerunkowi Indian znanemu z książek o Dzikim Zachodzie]. O Siouxach mówią nawet, że nie są tak waleczni jak Apaches i Comanches, mieszkający na Południu. [L 141]

\section{I tu Sienkiewicz dodaje wyjaśniający, aktualizujący korespondencję przypis:}

W czasie wojny, która wkrótce potem wybuchła, Siouxowie zadali kłam temu mniemaniu, wódz ich bowiem, Siedzący Byk, pokonał w krwawej bitwie wojska amerykańskie pod wodzą generała Custera, który zginął. [L 141]

Jest to jeden $z$ dwóch przypisów wzmiankujących człowieka uważanego za najbardziej dramatyczną postać wojen $z$ Indianami. W następnej mianowicie korespondencji relacjonującej dalszy ciąg podróży, zakończonej 16 marca w San Francisco, Sienkiewicz uzupełnia:

W chwili, w której to piszę (druga połowa lipca), w Czarnych Górach i ich pobliżu wojna wre już na dobre nie między górnikami a Indianami, lecz już między rządem Stanów Zjednoczonych i tymiż. Wedle ostatnich depesz wojska pod wodzą generała Custer poniosły dotkliwą klęskę. [L 166-167, przypis]

Wracając do spotkania Sienkiewicza $z$ Indianami, przypomnijmy jego pierwsze wrażenia i nieco późniejsze refleksje. $Z$ właściwym sobie ironicznym humorem opowiada on:

Po bliższym przyjrzeniu się im wyglądali obdarto, nadzwyczaj brudno i niechlujnie. Wydawali przy tym zapach mało co lepszy od skunksów, który jednak, szczęściem, łagodzony był przez dym palących się wrzosów. Gdyśmy zasiedli wraz z Francuzem bez wszelkich powitań i ceremonii przy ognisku, twarze wojowników pozostały równie nieruchome; nie obdarowali nas ani jednym spojrzeniem. Gdy jednak wydobyłem sporą paczkę cygar i czekolady i gdy Francuz oświadczył (co mi wytłumaczył później), iż młody wojownik z Północy, który należy do innego pokolenia białych, przyjaznego czerwonym, przychodzi zawrzeć znajomość z czerwonymi braćmi i składa im podarki - stoicyzm wojowników zniknął jak mgła. Twarze ich i oczy pozostały wprawdzie równie nieruchome, ale ozwało się przygłuszone, chrapliwe „halo!”, ogromne brązowe łapy wyciągnęły się łapczywie w kierunku podarków i tak czekolada, jak i cygara znikły natychmiast w paszczach moich nowych sprzymierzeńców. Przez chwilę słychać było 
tylko chrupotanie nieszczęsnych tabliczek czekolady ofiarowanych mi przez piękne rączki jeszcze w Warszawie, potem nastapiła uroczysta cisza.

Teraz już lody były złamane. Mogłem rozmawiać do woli, ale nim zdążyłem spytać o imiona braci moich i skomponować jakieś efektowne dla siebie, lokomotywa zagwizdała i trzeba było wracać. [...]

[...] W wagonie rozmowa toczyła się wszędzie o czerwonych. Trudno zrozumieć, do jakich granic dochodzi nienawiść i pogarda kresowych Amerykanów względem Indian. Prawda, że ciagła walka na śmierć i życie, grabieże i rozboje zaostrzają do wysokiego stopnia wzajemne stosunki; ale też prawda także, że pograniczni biali zupełnie nie uważają Indian za ludzi, wytępianie zaś ich poczytują za zasługę wobec ludzkości. Człowiek biały, według pojęć pogranicznych, ma takież samo prawo tępić Indian, jak grzechotniki, szare niedźwiedzie i inne szkodliwe stworzenia. Podczas więc gdy od czasu do czasu brukowi filantropowie w New Yorku wyprawiają filantropijne maskarady ze sprowadzonymi Indianami, na kresach wre ustawiczna wojna bezlitosna i najokrutniejsza, o jakiej można pomyśleć. Trzeba bowiem wiedzieć, że kresowcy, lubo względem siebie lojalni, a nawet uczciwi, w stosunku do czerwonoskórych nie są mniej dzikimi. Indianin nie ma litości, to prawda; ofiara, która wpadnie w jego ręce, na próżno używałaby wszelkich ludzkich zaklęć i próśb: czerwony wojownik patrzy na nią nieruchomymi oczyma, błagania przyjemnie tylko łechca jego uszy; męka ofiary sprawia mu rozkosz, nasyca się nią i przez chwilę jest szczęśliwy. Ale biali również postępują z nimi. Indianin zdziera skórę z głowy jeńca jako wojenne trofeum; biali przyjęli od czerwonoskórych ten zwyczaj i również skalpują swych jeńców. $Z$ tym wszystkim, gdyby mnie kto spytał, po czyjej stronie leży słuszność, to sądząc według zasad prostej, opartej nie na sofistyce, ale na sercu i sumieniu sprawiedliwości, odpowiedziałbym, że słuszność leży po stronie Indian.

Spojrzyjmy bowiem, co to jest i jak się im przedstawia owa cywilizacja, do której przyjęcia głosza ich niezdolnymi! Więc oto najprzód: rząd Stanów gwarantuje im ziemię, obywatele zaś, z których łona rząd wyszedł, odbierają im ją mimo rządu. Na pierwszym więc kroku spotykają się z kłamstwem i krzywoprzysięstwem, jako zaś proste dzieci natury nie umieją odróżnić rządu od narodu i z tych wszystkich stosunków wynoszą jedno tylko poczucie: głębokiej krzywdy. Zresztą Indianin w cywilizacji widzi tylko stratę tego wszystkiego, co stanowiło sposób do życia jego i jego przodków. Najprzód odejmują mu cały obszar stepów bez końca, a dają kawałek ziemi, której on nie umie uprawiać. Dają mu derkę, a zabierają wolność. Piękna zamiana! Dziki wojownik siedząc na grzbiecie mustanga przebiega stepy, poluje, walczy, oddycha całym obszarem piersi; jemu to życie dzikie, stepowe - potrzebne jak ptakowi powietrzne przestrzenie; on bez tego obejść się nie może: schnie i umiera. Pomyślmy zatem, co zyskuje, a co traci przyjmując tak zwaną cywilizację. Przede wszystkim mrze głód na swoim kawałku roli; ciż sami bracia, którzy prawili mu o cywilizacji, pogardzają nim teraz tak, jak w Europie Cyganem, a w rezultacie nic też innego nie pozostaje mu jak cygańskie życie: żebranina i małe złodziejstwa, i wegetowanie z dnia na dzień, wśród którego podleje do ostatka.

Na koniec, jacyż to są ci apostołowie cywilizacji, z którymi się spotyka? Najprzód kupiec, który go oszukuje; dalej awanturnik, który mu zdziera skórę z głowy; dalej traper, który przed jego wigwamem poluje na bawoły dostarczające czerwonym pożywienia; wreszcie amerykański komisarz rządowy z papierem, na którym między liniami napisano: Mane, tekel, fares! dla całego plemienia.

Spotykałem potem na wielu stacjach w stepach Nebraski i Wyomingu tak zwanych ucywilizowanych Indian. Jest to jeden obraz nędzy i rozpaczy: mężczyźni obdarci, brudni, upodleni; kobiety wyciagają wychudłe ręce do wagonów. Spytacie, dlaczego jedni i drugie nie pracują? Nie umieją; nikt się nie troszczy zresztą o to, żeby ich nauczyć. Wyrzekli się wojny z białymi, rozbojów, polowań, a dostali za to... derki... i pogardę.

Na koniec, najpierwszym bezpośrednim produktem, który wszyscy dzicy otrzymali od cywilizacji, jest: wódka, ospa i syfilis; cóż dziwnego więc, że patrząc na cywilizację ze stanowiska tych najpierwszych dobrodziejstw, nie wzdychają do niej, bronią się i giną!

Przede wszystkim zaś giną. Całe te plemiona, czy to przyjąwszy cywilizację, czy żyjąc w stanie dzikim, znikają z powierzchni ziemi z zastraszającą szybkością. Nie mogą się cywilizacji ani oprzeć, ani unieść na słabych ramionach jej ciężaru. Objaw to spotykany u wielu ludów dzikich. Uczony nasz rodak Strzelecki, sprawdziwszy go, zmienił na „prawo naukowe”, które Anglicy „Strzelecki law” przezwali i które stale dziś już jako pewnik przyjęte jest przez antropologię. Co do Indian jednakże, a przynajmniej co do niektórych ich pokoleń, są bowiem wielkie między nimi różnice, gdyby zamiast spotykać się z mętami cywilizacji, zetknęli się $\mathrm{z}$ lepszą, łagodną i ochraniająca, a nie niszczącą jej stroną, może by na koniec przywykli do niej i ocaleli od zguby. Cywilizacja taka winna jednakże być nader łagodną nauczy- 
cielką i naginać z wolna, a nie od razu łamać. Zmiana sposobu życia, stałe osiedlenie i zajęcie się rolą, które wobec dzisiejszych stosunków przedstawiają się jako konieczność narzucona gwałtem nieprzygotowanym do niej plemionom, przyszłyby wówczas $z$ wolna jako naturalne następstwa stopniowego rozwoju.

Zdaje mi się nawet, że owo prawo naukowe o koniecznej zagubie ludów spotykających się z cywilizacją daje się wyjaśnić nie absolutną niezdolnością tych ludów, ale tym właśnie, że nie mają czasu cywilizować się tak, jak cywilizowały się ludy europejskie, to jest drogą ciagłego i stopniowego rozwoju. Żyjąc częstokroć w stanie zupełnie pierwotnym, czasem nawet ludy żerujące (Sammelvölker), dzikie plemiona spotykają się od razu z cywilizacją wysoką, rozwiniętą, subtelną - słowem: z cywilizacją absolutnie dla nich za trudną; nic więc dziwnego, że zamiast pod jej wpływem podnosić się i oświecać, tumanieją, głupieją i w rezultacie rozbijają sobie o tę zbyt twardą na ich zęby cywilizację głowy.

Wracam jeszcze raz do Indian: słyszałem od ludzi doświadczonych, a później przekonałem się osobiście, że są to plemiona względnie dość nawet rozwinięte umysłowo. Nie stoją na przykład wcale o wiele niżej od Kałmuków, Baszkirów i innych plemion koczujących na stepach Rosji i Azji; mają swoje podania, swoją mitologię, a nawet swoją poezję, zawierającą się w pieśniach wojennych, pieśniach śmierci i tym podobnie. Podania niektóre są nawet nader zręcznie ułożone i dowodzą pewnego sprytu, umiejącego korzystać z zewnętrznego materiału, jakiego dostarczają ludzie i przyroda. Gdy wielki Manitu (mówi jedno z podań) postanowił stworzyć człowieka, wziął glinę, wyrobił kształt ludzki i postanowił go wypalić w ogniu. Ale pierwszym razem przepalił na węgiel, twór jednak zostawił przy życiu i stąd powstał czarny Murzyn; drugim razem nie dopiekł i powstał biały człowiek; trzeci raz dopiero, nauczony doświadczeniem, umiał zachować miarę: nic nie dopiekł, nie przepalił i stąd powstał twór doskonały, prawdziwie piękny: czerwonoskóry.

Jest w tym podaniu pewna trafność, polegająca na umiejętnym skorzystaniu $z$ koloru trzech ras ludzkich. Dalej, sam sposób wyrażania się Indian, w najzwyklejszej nawet mowie pełen porównań i metafor, do wysokiego stopnia jest poetyczny i dowodzacy pewnego wyrobienia się myśli. W niektórych indywiduach wrodzona inteligencja po prostu jest zadziwiającą, ale w ogóle wszyscy są nader przenikliwi, umiejący odróżnić prawdę od kłamstwa, choćby najbardziej cukrowego. Cechy te mieszają się wprawdzie, $z$ drugiej strony, $z$ naiwnością prawie dziecięcą.

Na koniec plemiona te, bądź co bądź, wyrobiły już pewną cywilizację, mogłyby więc postępować i dalej, mogłyby stanąć przy mądrej pomocy i na wysokości naszej cywilizacji - gdyby nie to, że ta nasza wynalazła postępowanie o wiele krótsze: zamiast słabszych popierać i wzmacniać - zabija. [L 141-147]

Ponieważ historia wojny przeciw Indianom i jej tragiczny bohater to sprawy stosunkowo mało znane w Polsce, warto przypomnieć nieco faktów świadczących o skali konfliktu, który przyniósł obu walczacym stronom tragiczne rezultaty, co uważny kronikarz skwapliwie odnotował. Kim był Custer, dziś uznawany za niemal narodowego bohatera, prototyp śmiałych dowódców, takich jak George Patton, najsłynniejszy $z$ amerykańskich generałów podczas drugiej wojny światowej?

George Armstrong Custer urodził się w roku 1839, miał więc w omawianym okresie zaledwie 39 lat, choć wyróżnić się zdołał w poprzednich kampaniach i dosłużył się stopnia generała brygady. Wysoki, przystojny, z długimi do ramion włosami, Custer był postacią ogromnie malowniczą. W ostatniej fazie zbrojnego konfliktu powierzono mu dowództwo 7 pułku kawalerii ( $7^{\text {th }}$ U.S. Cavalry) i skierowano w stronę Czarnych Gór, gdzie nad rzeką Little Bighorn legendarny wódz Siuksów Lakota, Sitting Bull, zgromadził około 3500 wojowników zdecydowanych bronić swojego terytorium przed wojskami dowodzonymi przez Custera. Jednym z wodzów w ugrupowaniu Sitting Bulla był Crazy Horse (Szalony Koń), którego postać obrosła legendą do tego stopnia, że żyjący w Stanach Zjednoczonych polski rzeźbiarz Korczak Ziółkowski postanowił wykuć w skale jego ogromny pomnik, do dzisiaj nie ukończony. Generał Custer dysponował siłą wielokrotnie mniejszą: armią licząca 
około 600 żołnierzy i oficerów, ale zaprawiona w bojach, dobrze zorganizowaną i wyekwipowaną. 17 maja 1876 Custer wyruszył z Fortu Abraham Lincoln w Północnej Dakocie, położonego w pobliżu dzisiejszego miasta Bismarck, a po tygodniu, 25 maja, zwiadowcy zawiadomili go o poważnym skupisku Indian zgromadzonych nad Little Bighorn nieopodal miejscowości zwanej Crow's Nest. Custer podzielił swoją armię na trzy bataliony i oddział transportowy w sile około 130 ludzi. Batalion kapitana Benteena miał trzy kompanie, liczące łącznie 125 osób, podczas gdy generał prowadził pozostałe osiem kompanii obejmujących około 200 żołnierzy, z których niebawem wydzielił batalion złożony z trzech kompanii, a dowodzenie nimi powierzył majorowi Reno. Ten oddział zaatakowany został przez Indian i praktycznie zniszczony. Indianie podjęli następnie brawurowy atak na batalion Custera, który po krótkiej, bezlitosnej walce wycięli w pień. Pozostałe połączone siły Reno i Benteena broniły się przez 36 godzin, do popołudnia 26 czerwca, kiedy Indianie odstapili. W sumie pułk stracił 268 ludzi $\mathrm{z}$ dowódcą na czele - wobec 30 do 100 poległych Indian.

Niektórzy historycy tej wojny krytykują Custera za nieprzemyślany atak na nieopisanie liczniejszego nieprzyjaciela, Sienkiewiczowi natomiast ta nierówna walka miała wkrótce posłużyć do stworzenia w Ogniem i mieczem obrazu bitwy nad Żółtymi Wodami, zakończonej klęską wojsk polskich toczących bój przeciw masom oddziałów kozackich i tatarskich ${ }^{2}$. Podobnie jak przebity strzałą Stefan („młody Potocki”, jak go Sienkiewicz nazywa), dowodzący wojskami Rzeczypospolitej, tak i Custer zginął od jednej kuli, broniąc się do końca $\mathrm{z}$ niewielka grupką żołnierzy na wzgórzu nazwanym później jego imieniem. Ta ostatnia śmiertelna potyczka przeszła do narodowej legendy jako „Custer's last stand [ostatni bój Custera]”, wspomagając bogaty folklor i literaturę poświęconą generałowi. Lawrence A. Frost, autor książki o legendach związanych z generałem Custerem, pisze:

Szereg biografów utrzymuje ruch wahadła opinii za i przeciw Custerowi. Niektórzy ze współczesnych obniżają jego wartość, podczas gdy jeden z wcześniejszych sportretował go jako połączenie Sir Galahada i Joanny d'Arc ${ }^{3}$.

I dodaje: „Znawcy twierdza, że tylko o Waszyngtonie i Lincolnie napisano więcej

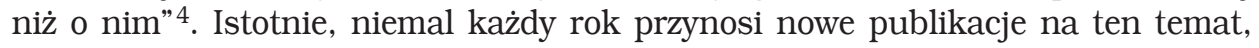
a fotografie Custera, przystojnego, postawnego kawalerzysty, pojawiają się na ich kartach i okładkach, przyczyniając się do podtrzymania mitu narodowego bohatera poległego w boju o obecny kształt Stanów Zjednoczonych. Postać generała została jakiś czas temu przypomniana w popularnym filmie Mały Wielki Człowiek (1970), ze znanym aktorem Dustinem Hoffmanem w roli głównej.

Wydaje się, że wpływ tej legendy na Sienkiewicza, a tym samym na literaturę polską, nie powinien budzić wątpliwości.

2 H. Sienkiewicz, Ogniem i mieczem. Cz. 1. W: jw., t. 7 (1949), s. 196-219. Zob. też biografię Custera: E. Conne11, Son of a Morning Star. San Francisco 1984, oraz zarys historyczny: R. A. Fox Jr., Archeology, History, and Custer's Last Battle: The Little Big Horn Reexamined. Foreword W. R. W o od. Norman 1993.

3 L. A. Frost, Custer Legends. Bowling Green, Ohio, 1981, s. 7.

4 Ibidem. 
Do tematyki indiańskiej miał Sienkiewicz powrócić w dwóch opowiadaniach napisanych podczas pobytu w Kalifornii: Orso i Sachem. Bohater pierwszego z nich, 16-letni siłacz występujacy w cyrku, jest półkrwi Indianinem (,zrodzony z ojca białego a matki Indianki”, N 155), który po indiańskich przodkach odziedziczył nie tylko wygląd, ale także dziką siłę - gdy dochodzi między nim a niemieckim dyrektorem cyrku do konfliktu w związku $\mathrm{z}$ mała Jenny, Orso potrafi zwyciężyć w walce i z okrutnym dyrektorem, i z jego murzyńskimi pomocnikami; potem zabiera dziewczynke w pustynne góry Santa Ana, gdzie napotkany starzec-pustelnik udziela im schronienia i zapewnia opiekę na przyszłość. Warto dodać, że imię i potężna siła bohatera przypadły w udziale również postaci Ursusa w Quo vadis.

Opowiadanie Sachem ma znacznie bardziej dramatyczny, ironiczny i gorzki charakter. Akcja rozgrywa się w niemieckim cyrku, tym razem nie w Kalifornii, ale w Teksasie, w miasteczku Antylopa, gdzie:

z mocy prawa „lynch" powieszono na placu miejskim dziewiętnastu ostatnich wojowników z pokolenia Czarnych Wężów, schwytanych w pobliskim lesie Umarłych - i odtąd nic nie stało na zawadzie rozwojowi Antylopy. [...] Na placu, na którym powieszono ostatnich Czarnych Wężów, zbudowano zakład filantropijny; pastorowie w kościołach uczyli co niedziela miłości bliźniego, poszanowania cudzej własności i innych cnót, potrzebnych ucywilizowanemu społeczeństwu; pewien przyjezdny prelegent miał nawet raz na Kapitolu odczyt O prawach narodów. [N 182]

Niemieccy mieszkańcy miasteczka mieli tłumnie zjawić się na występach „słynnego gimnastyka, Czerwonego Sępa, sachema (wodza) Czarnych Wężów, ostatniego potomka królów pokolenia i ostatniego z pokolenia” (N 183). Sachem pojawia się na arenie:

Wydaje się dumny jak król. Płaszcz z białych gronostajów - oznaka wodza - pokrywa jego wyniosłą postać i tak dziką, że przypomina źle oswojonego jaguara. Twarz ma jakby wykutą z miedzi, podobną do głowy orła, a w tej twarzy świeca zimnym blaskiem oczy prawdziwie indyjskie, spokojne, niby obojętne - a złowrogie. Wodzi on nimi po zgromadzeniu, jakby chciał sobie upatrzyć ofiarę. [N 187]

Toteż kiedy sachem rozpoczyna swoją pieśń („śpiewa po niemiecku”, N 188), strach pada na słuchających, opowieść mówi bowiem o zniszczeniu indiańskiego osiedla przez białych, o nieuchronnej zemście, pożodze i krwi... Aż wreszcie, gdy zdawało się, że rzuci się na białych i spali ich wraz z całym cyrkiem, sachem niespodziewanie znika $z$ areny, po to tylko, żeby powrócić z blaszaną miska - „wyciągając ją ku widzom, mówi błagalnym głosem: Was gefällig für den letzten der Schwarzen Schlangen!... [Co łaska dla ostatniego z Czarnych Wężów]” (N 189). Sienkiewicz ironicznie konkluduje:

Po przedstawieniu sachem pił piwo i jadł knedle „Pod Złotym Słońcem”. Otoczenie wpływ widocznie wywarło. Zyskał wielką popularność w Antylopie, zwłaszcza u kobiet. Robiono nawet plotki... [N 189]

A jak wyglądają sprawy Indian dzisiaj, po przeszło 100 latach zarówno od bitwy nad Little Bighorn, jak i od czasu akcji w opowiadaniach Sienkiewicza? Co się zmieniło na lepsze czy na gorsze? O odpowiedź na te pytania pokusiła się ostatnio doskonale w tych problemach zorientowana Aleksandra Ziółkowska-Boehm w książce symptomatycznie zatytułowanej Otwarta rana Ameryki (Bielsko-Biała 2007). Nie trzeba dodawać komentarza, gdyż - jak mawiali starożytni - „, sapienti sat”. 
Abstract

JERZY R. KRZYŻANOWSKI Columbus State University, Ohio, USA

\section{SIENKIEWICZ, GENERAL CUSTER AND INDIANS}

The article presents Henryk Sienkiewicz as the author of reports written during his stay in the USA between 1876-1878 and published in "Gazeta Polska" ("Polish Gazette") as Listy z podróży do Ameryki (Letters from America). It focuses mostly on the account from his meeting with the Sioux, two months before general Custer's famous Battle of the Little Bighorn River with the Indians, on the impressions from this meeting and on Sienkiewicz's further reflections connected with it, as well as sketches the circumstances of the mentioned battle. The article concludes with the remarks on Sienkiewicz's return to Indian issues in his short stories Orso and Sachem. 